\title{
Temperature-Pressure Phase Relationships in Niobium Pentoxide
}

\author{
J. L. Waring, R. S. Roth, and H. S. Parker \\ Institute for Materials Research, National Bureau of Standards, Washington, D.C. 20234
}

(July 23, 1973)

\begin{abstract}
A pressure-temperature $(P-T)$ section of the phase equilibrium diagram for $\mathrm{Nb}_{2} \mathrm{O}_{5}$ has been determined. Four single phase regions, $\mathrm{H}-\mathrm{Nb}_{2} \mathrm{O}_{5}, \mathrm{~B}-\mathrm{Nb}_{2} \mathrm{O}_{5}$, and two $\mathrm{L}-\mathrm{Nb}_{2} \mathrm{O}_{5}$ areas, were characterized by x-ray powder diffraction data. The superstructure of $\mathrm{L}-\mathrm{Nb}_{2} \mathrm{O}_{5}$ was indexed on the basis of similarities to the known superstructures of $\mathrm{L}_{-} \mathrm{Ta}_{2} \mathrm{O}_{5}$ and confirmed with single crystal electron diffraction data. The correct unit cell is orthorhombic with $a=6.168, b=29.312, c=3.938 \AA$, with the $b$ axis 8 times the subcell $(8 \times 3.664 \AA)$.
\end{abstract}

Key words: Niobium pentoxide; phase relationships; pressure; temperature.

\section{Introduction}

Niobium pentoxide has been reported to occur in at least eight different polymorphic forms under varying experimental conditions. The polymorphs of $\mathrm{Nb}_{2} \mathrm{O}_{5}$ and their structural relationships to each other have been discussed by A. D. Wadsley and S. Andersson [1]. ${ }^{1}$ These authors postulated that some of the various modifications should have stability fields in the relevant ranges of the pressure-temperature $(P-T)$ phase diagram. They put forward a "not impossible" phase diagram (fig. 1) based on no experimental evidence. S. Tamura [2] reported a temperaturepressure diagram (fig. 2) for $\mathrm{Nb}_{2} \mathrm{O}_{5}$ postulating the boundaries between $\mathrm{H}-\mathrm{Nb}_{2} \mathrm{O}_{5}$ and $\mathrm{L}^{-\mathrm{Nb}_{2} \mathrm{O}_{5}}$ and B- $\mathrm{Nb}_{2} \mathrm{O}_{5}$ and $\mathrm{L}-\mathrm{Nb}_{2} \mathrm{O}_{5}$ based on experiments utilizing an opposed piston apparatus. $\mathrm{H}-\mathrm{Nb}_{2} \mathrm{O}_{5}$ is the stable polymorph which occurs at high temperatures and atmospheric pressure, $\mathrm{L}-\mathrm{Nb}_{2} \mathrm{O}_{5}$ is the metastable polymorph formed during precipitation and $\mathrm{B}-\mathrm{Nb}_{2} \mathrm{O}_{5}$ is the high pressure form [1]. In the present study only these three previously reported phases were found to occur in the system at the temperatures and pressures studied.

In this study, it was necessary to determine which of the multitude of possible polymorphs represent equilibrium phases and which represent metastable phases. The $\mathrm{Nb}_{2} \mathrm{O}_{5}$ specimens were equilibrated in an apparatus which is capable of heating materials in a uniform temperature zone up to about $1400{ }^{\circ} \mathrm{C}$ and $150,000 \mathrm{psi}^{2}$ isostatic pressure in an environment free of contaminants. \footnotetext{
${ }^{1}$ Figures in brackets indicate the literature references at the end of this paper.
${ }^{2}$ The use of psi, bar, and kbar follows the current common practice of workers in the field. Note that $1 \mathrm{bar}=10^{5} \mathrm{~N} / \mathrm{m}^{2}$ (or pascal) $=10^{6} \mathrm{dyn} / \mathrm{cm}^{2}=0.9869 \mathrm{~atm}=14.504 \mathrm{psi}$. The accepted international standard (SI) unit of pressure is the pascal or newton per meter accepted
squared.
}

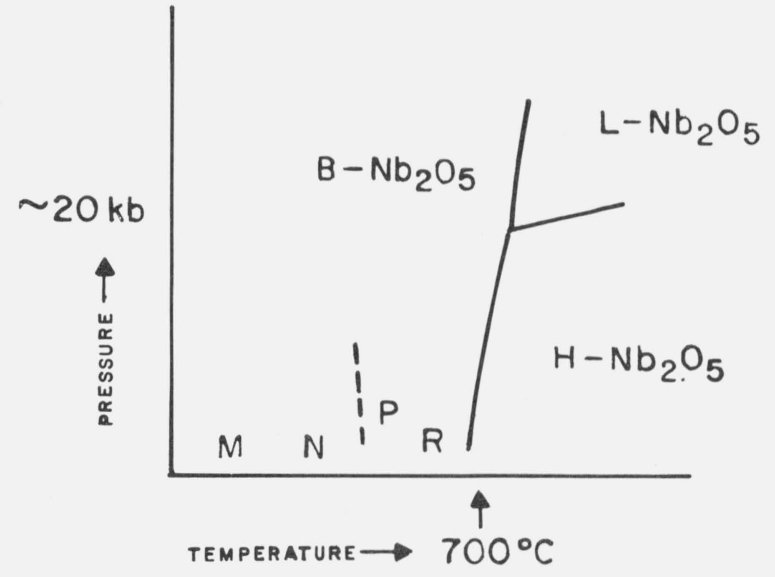

Figure 1. Tentative temperature-pressure phase diagram for various $\mathrm{Nb}_{2} \mathrm{O}_{5}$ modifications (taken from $W$ adsley and Andersson [1] and modified according to present notation).

\section{Sample Preparation}

The $\mathrm{Nb}_{2} \mathrm{O}_{5}$ used in this investigation was found by spectrographic analysis to contain less than about 0.01 percent $\mathrm{Si}, 0.001$ percent $\mathrm{Ca}$ and $\mathrm{Mg}$. The presence of $\mathrm{As}, \mathrm{Cu}$, and $\mathrm{Ta}$ was questionable. The starting materials were prepared as follows: The $\mathrm{Nb}_{2} \mathrm{O}_{5}$ (low temperature form) was dried at $130{ }^{\circ} \mathrm{C}$ for $19 \mathrm{~h}$. Portions of the dried material were sealed in $5 \mathrm{~mm}$ O.D. $\times 25 \mathrm{~mm}$ long $\mathrm{Pt}$ tubes and heated to $1450{ }^{\circ} \mathrm{C}$ for $60 \mathrm{~h}$ to form $\mathrm{H}-\mathrm{Nb}_{2} \mathrm{O}_{5}$, the high temperature polymorph. This material was reannealed in air at $1000^{\circ} \mathrm{C}$ for $1 \mathrm{~h}$ to minimize any slight reduction which may have occurred. The B-polymorph of $\mathrm{Nb}_{2} \mathrm{O}_{5}$ was formed by heating the high temperature modification $\left(\mathrm{H}-\mathrm{Nb}_{2} \mathrm{O}_{5}\right)$ 


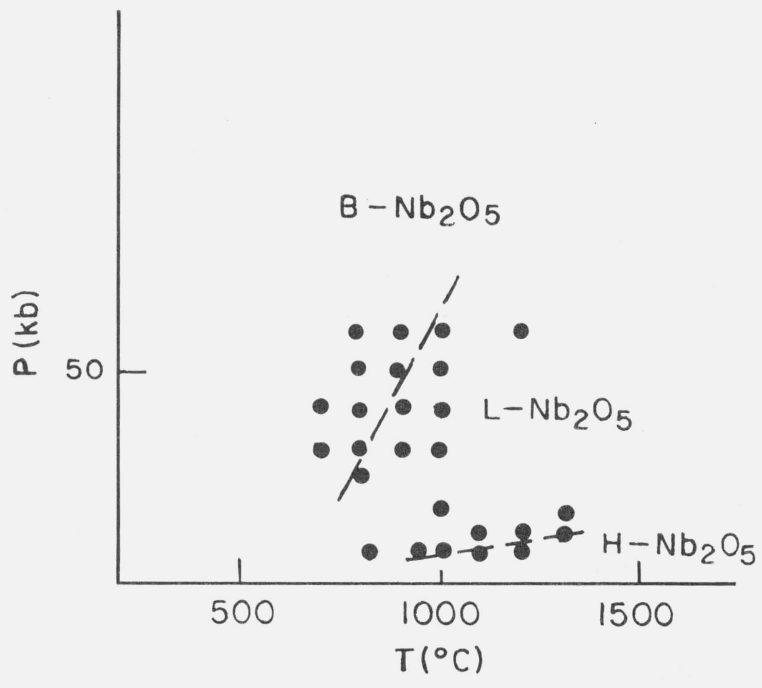

FIGURE 2. Pressure/temperature/structure relationships for $\mathrm{Nb}_{2} \mathrm{O}_{5}$ (after Tamura [2]).

at $900{ }^{\circ} \mathrm{C}$ for $19 \mathrm{~h}$ at about 70,500 psi. For some experiments, $\mathrm{LiNbO}_{3}$ or distilled $\mathrm{H}_{2} \mathrm{O}$ was added to increase crystallinity and to determine if such impurities affect the equilibrium phase assemblage.

\section{Apparatus}

An internally heated pressure system similar to that described by Yoder [3] was used in this investigation. A block diagram of the apparatus is shown in figure 3. An air operated, two stage compressor (labeled A) supplies argon gas to the system at pressure to 30,000 psi. For higher initial pressures the valve (labeled B) is closed and the moving piston of an intensifier (labeled C) is advanced against the head of gas which has filled the vessel. The intensifier piston is advanced by hydraulic pressure supplied by an air driven oil compressor. The differential ratio of the intensifier is $5: 1$ thus providing a maximum pressure of 150,000 psi. The valve (labeled D) isolates the pressure vessel during a run. Pressures of up to 150,000 psi can be obtained in a few minutes provided the system is tight. Since a minimum of $16 \mathrm{~h}$ was needed to achieve equilibrium in most of the samples studied, at least in the lower $P-T$ range, particular attention had to be paid to obtaining a relatively leak free system. Experimental results were discarded if a pressure drop greater than 500 psi occurred during a run.

\subsection{Pressure Measurement}

The pressure was determined as a function of the change in resistance of a "seasoned" manganin wire coil when measured with a dc Carey-Foster Bridge [4]. The resistance of the manganin coils was approximately equal to $120 \Omega$ and the coils were calibrated by the supplier against a dead weight gage. Two coils were used for a comparison measurement. One coil acted as a pressure sensor and the other served as a

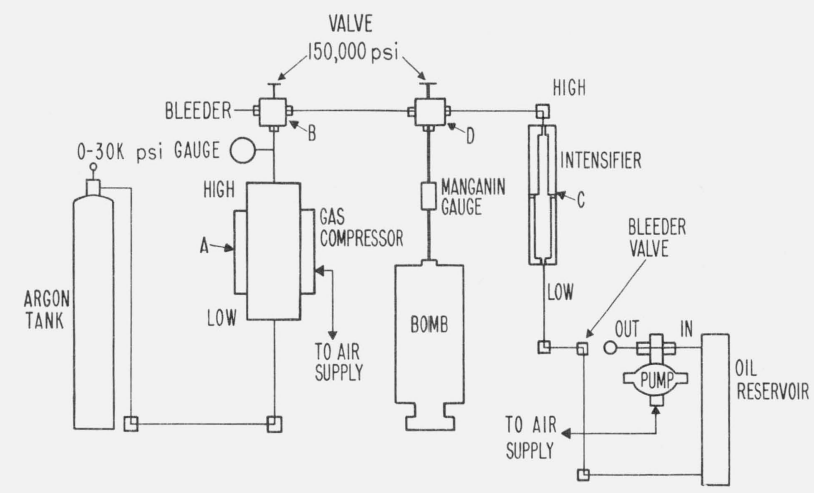

FigURE 3. Schematic block diagram of pressure-temperature apparatus having a working range up to $1400^{\circ} \mathrm{C}$ and 150,000 p.s.i.

dummy gage for temperature compensation. A least squares fit by computer analysis of the correction data for the manganin coils used in this study has shown that the resistance-pressure curve in the range $0-150,000$ psi can be described best by a parabolic equation of the type $R=B_{0}+B_{1} P+B_{2} P^{2}$ where $B_{0}=1.20357$, $B_{1}=1.9926470 \times 10^{-5}$ and $B_{2}=8.0085893 \times 10^{-13}$. Errors in absolute pressure may be as much as 20 bar at 150,000 psi due to uncertainties in the pressure scale [3].

\subsection{Temperature Measurement}

The temperature was measured with a Pt-Pt10 percent Rh thermocouple. Bell [5] has shown that the effect of pressure on $\mathrm{Pt}-10$ percent Rh thermocouples at the pressures attained in this work are within the limits of error in the temperature measurement. For this reason no correction for pressure has been applied to the temperature measurements. The temperatures reported can be considered accurate to at least $\pm 20^{\circ} \mathrm{C}$. Yoder [3] reported the results of probing the thermal gradient of his system with a thermocouple. A zone of even heating $\pm 5^{\circ} \mathrm{C}$ was found to exist over a distance of about $5 \mathrm{~cm}$. As our system is nearly identical, this time consuming process was not repeated.

\section{Phase Equilibria}

A $P-T$ phase equilibrium diagram for $\mathrm{Nb}_{2} \mathrm{O}_{5}$ (fig. 4) has been constructed from the x-ray data given in table 1 . These data were obtained from specimens quenched (thermocouple indicates cooling to ambient temperature in less than a minute) by turning off the electrical power to the furnace and then reducing the pressure. Equilibrium was considered to have been approached when the x-ray powder diffraction patterns of specimens successively heated for longer times and/or at higher temperatures and/or pressures (quenched to ambient temperature and pressure) showed no significant change. X-ray diffraction powder patterns were made using a high angle record- 


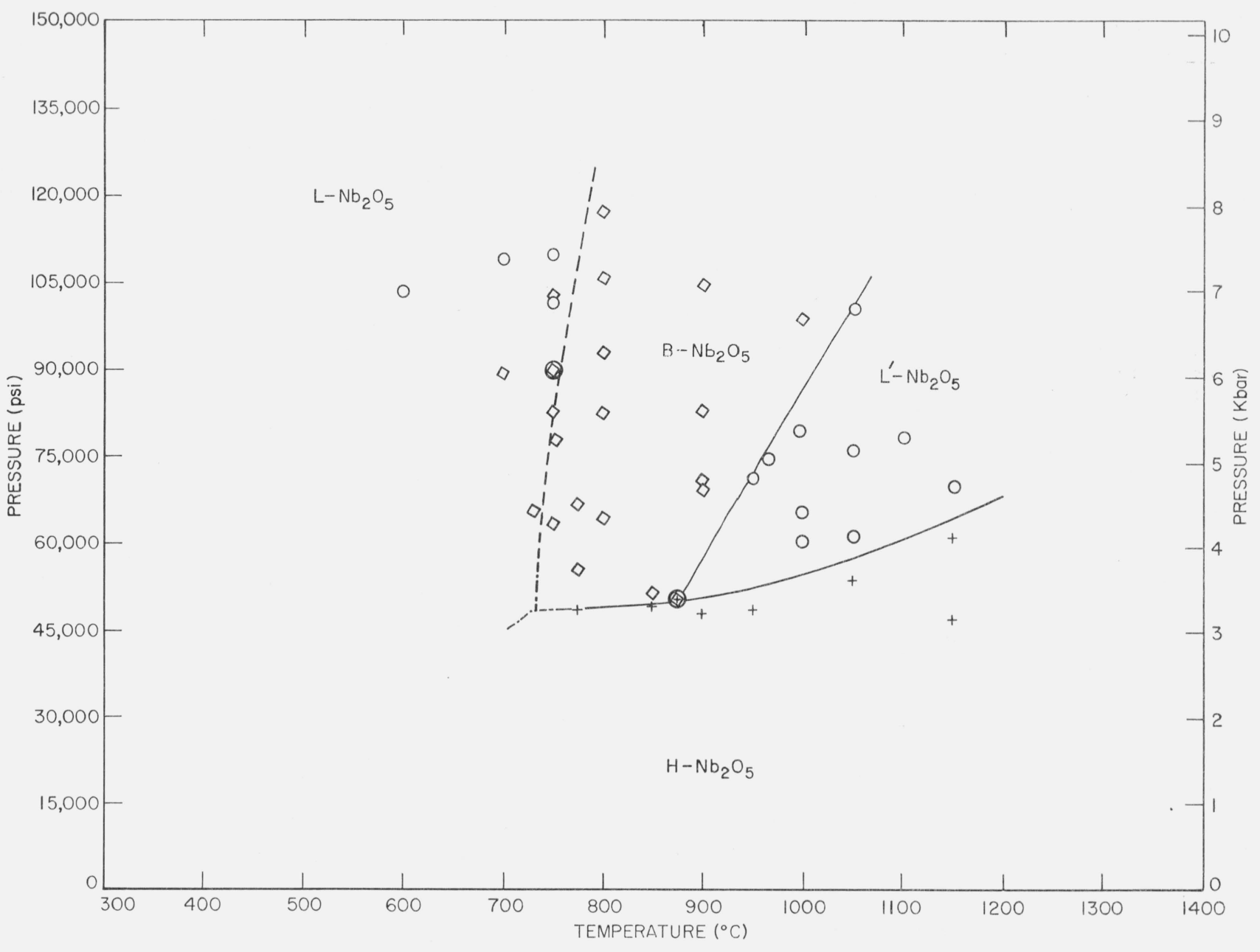

Figure 4. Pressure-temperature (P-T) phase equilibrium diagram for $\mathrm{Nb}_{2} \mathrm{O}_{5}$.

Dot dash curves-delineate phase boundaries which could not be determined. Dashed curve-delineates phase boundaries where reversibility was not established.

Symbols refer to phases interpreted as equilibrium (see table 1 for experimental data).

ing Geiger counter diffractometer and nickel-filtered copper radiation with the Geiger counter scanning the $2 \theta$ angular range at $1 / 4^{\circ} 2 \theta / \mathrm{min}$ and the radiation being recorded on the chart at $1^{\circ} 2 \theta /$ in. The unit cell dimensions reported are estimated to be accurate within about two standard deviations.

The phase diagram can be described as consisting of four single phase regions in the temperaturepressure range investigated. They are designated $\mathrm{H}-\mathrm{Nb}_{2} \mathrm{O}_{5}, \quad \mathrm{~L}-\mathrm{Nb}_{2} \mathrm{O}_{5}, \quad \mathrm{~B}-\mathrm{Nb}_{2} \mathrm{O}_{5}$ and $\mathrm{L}^{\prime}-\mathrm{Nb}_{2} \mathrm{O}_{5}$. In a previous study the $\mathrm{N}$-form of $\mathrm{Nb}_{2} \mathrm{O}_{5}$ was synthesized at atmospheric pressure with the addition of $\mathrm{LiNbO}_{3}$ [6]. However, in the present study this phase was found to transform to $\mathrm{B}-\mathrm{Nb}_{2} \mathrm{O}_{5}$ at $800{ }^{\circ} \mathrm{C}$ and 64,000 psi and may be considered to become unstable with increasing pressure. No other polymorphs of $\mathrm{Nb}_{2} \mathrm{O}_{5}$ have been found to occur in this study.

\section{1. $\mathrm{H}-\mathrm{Nb}_{2} \mathrm{O}_{5}$ (High Temperature Form)}

The crystal structure of the high temperature form of $\mathrm{Nb}_{2} \mathrm{O}_{5}\left(\mathrm{H}-\mathrm{Nb}_{2} \mathrm{O}_{5}\right)$ was reported by Gatehouse and Wadsley [7]. The structure consists of infinite chains of $3 \times 5$ blocks of octahedra at one level and isolated blocks of $3 \times 4$ octahedra at the next level with tetrahedral positions at the block junctions. This phase, with a reported x-ray density of 4.55 [8], was found to occur at the highest temperature and lowest pressure (fig. 4). All experiments conducted in the $P-T$ range lower than that given in table 1 and figure 4 showed no change in the starting material. Therefore, the low temperature boundary of the $\mathrm{H}-\mathrm{Nb}_{2} \mathrm{O}_{5}$ field could not be determined because equilibrium could not be achieved in this portion of the system in laboratory time. 
Table 1. Temperature-Pressure Experimental Data
for $\mathrm{Nb}_{2} \mathrm{O}_{5}$.

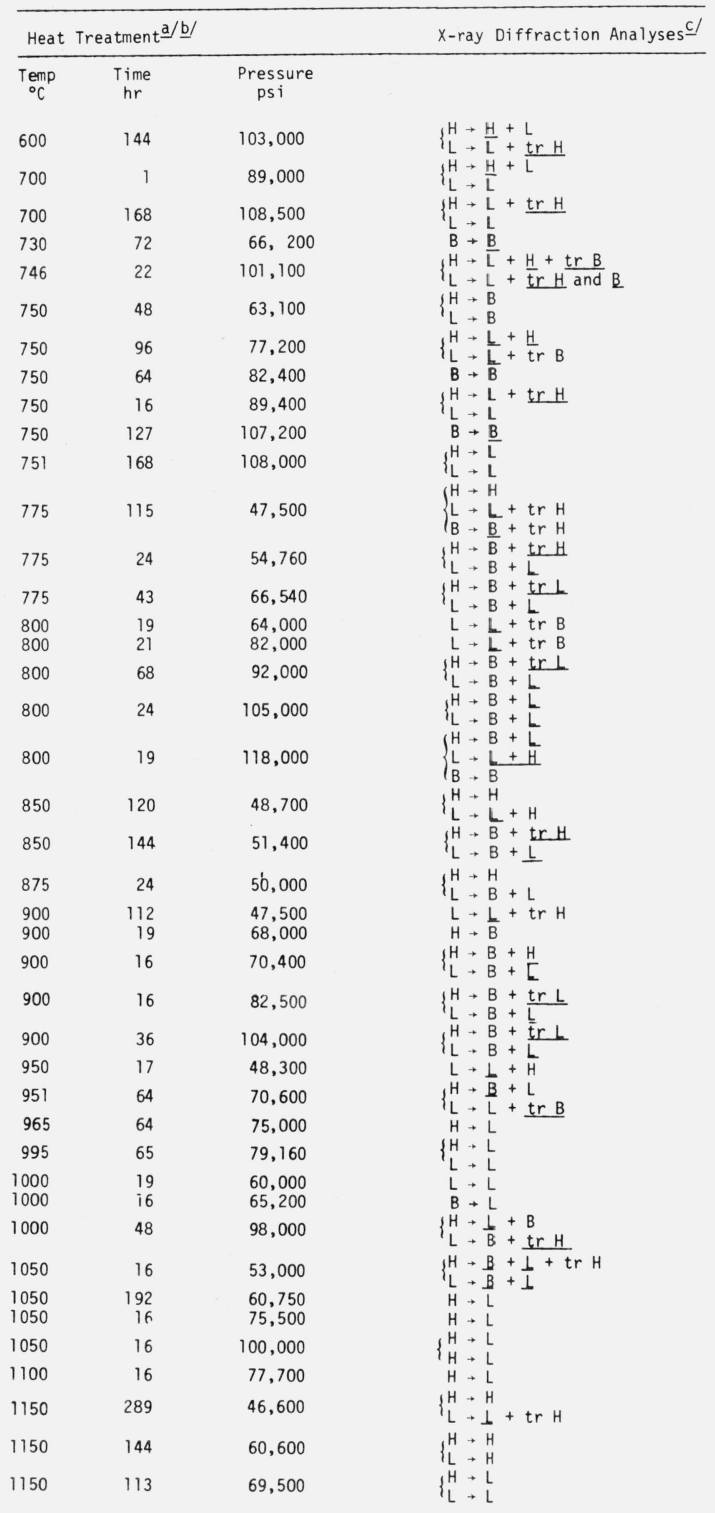

a/ The starting materials were prepared as follows: $\mathrm{L}-\mathrm{Nb}_{2} \mathrm{O}_{5}$ dried at $130^{\circ} \mathrm{C}$ for 19 hours, $\mathrm{H}-\mathrm{Nb}_{2} \mathrm{O}_{5}$ - calcined at $1450^{\circ} \mathrm{C}$ for 60 hours in large sealed $\mathrm{Pt}$ tube and reannealed in air at $1000^{\circ} \mathrm{C}$ for one hour. $\mathrm{B}-\mathrm{Nb}_{2} \mathrm{O}_{5}-\mathrm{H}-\mathrm{Nb} 2_{2} \mathrm{O}_{5}$ was heated at
$900^{\circ} \mathrm{C}$ for 19 hours in a series of small $\mathrm{Pt}$ tubes at a pressure $900^{\circ} \mathrm{C}$ for 19 hours
of 70,500 psi.

b/ All specimens were quenched in sealed Pt tubes. Some specimens were heated at appropriate temperatures in Au tubes and it was found that for $\mathrm{Nb}_{2} \mathrm{O}_{5}$ the experimental results were the same for both the Pt and Au tubes.

c/ The phases identified are given in the order of the amount present at room temperature. The phases are not necessarily those present at the temperature and pressure to which the specimen was heated.

$$
\begin{aligned}
& H=\text { high temperature-low pressure polymorph of } \mathrm{Nb}_{2} \mathrm{O}_{5} \\
& \mathrm{~L}-\mathrm{Nb}_{2} \mathrm{O}_{5}=\text { represents both } \mathrm{L}-\mathrm{Nb}_{2} \mathrm{O}_{5} \text { and } \mathrm{L}^{\prime} \mathrm{Nb}_{2} \mathrm{O}_{5} \text { which } \\
& \text { occur experimentally in two different portions of } \\
& \text { the system separated by the field of } \mathrm{B}-\mathrm{Nb}_{2} \mathrm{O}_{5} \text {. The } \\
& \text { x-ray patterns of the specimens prepared in these } \\
& \text { two fields are identical except for degree of } \\
& \text { crystallinity. } \\
& \mathrm{B}=\text { intermediate temperature and high pressure polymorph } \\
& \text { of } \mathrm{Nb}_{2} \mathrm{O}_{5} \text {. }
\end{aligned}
$$

The phase(s) underlined have been interpreted as non-equilibrium under the specified temperature-pressure conditions.
Table 2. Indexed X-ray Diffraction Powder Pattern for $\mathrm{B}_{-} \mathrm{Nb}_{2} \mathrm{O}_{5}$ (CuKa radiation) $\underline{\mathrm{a}}$ /

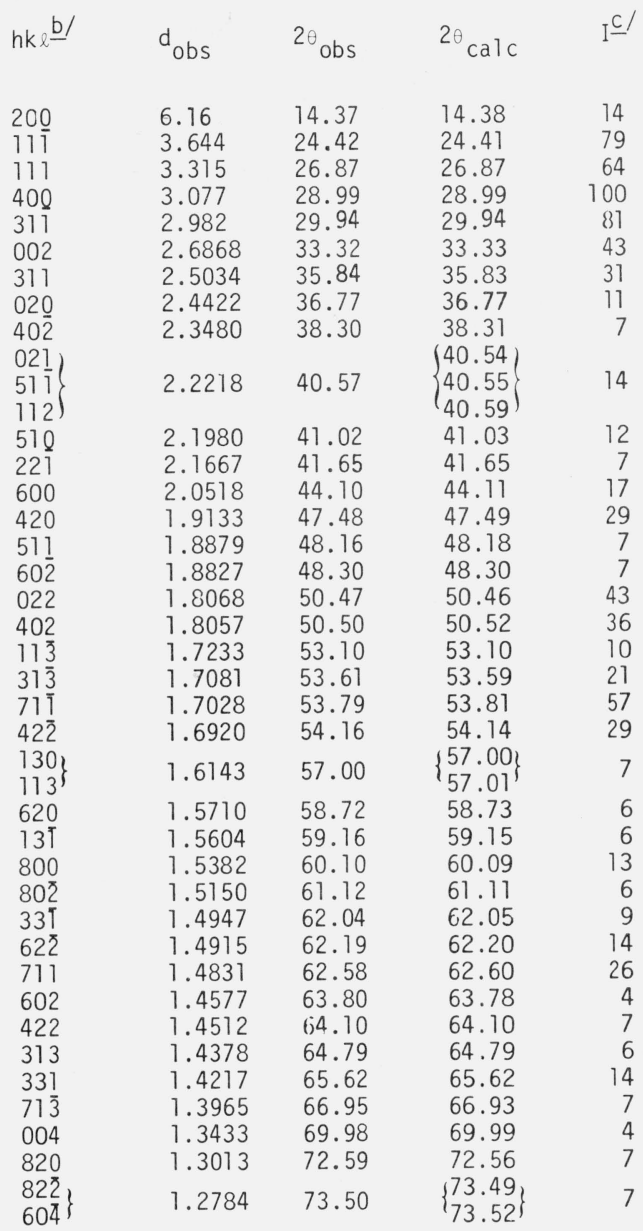

a/ Specimen heated to $900^{\circ} \mathrm{C}$ for $19 \mathrm{hrs}$ at 70,500 psi in a sealed Pt tube and quenched.

b/ Indexed on the basis of a monoclinic unit cell $\underline{a}=12.744 \pm 0.001 \AA, b=4.8845+0.0006 \AA, c=5.5629: 0.0006 \AA$ and $\beta=105^{\circ} 1.9^{\prime} \div 0.5^{\prime}$.

c/ Observed intensity, peak height.

\section{2. $\mathrm{B}-\mathrm{Nb}_{2} \mathrm{O}_{5}$}

The existence of $\mathrm{B}-\mathrm{Nb}_{2} \mathrm{O}_{5}$ was first reported by Laves, Petter and Wulf [9] who described it as zeta$\mathrm{Nb}_{2} \mathrm{O}_{5}$. Schäfer, Schulte, and Gruehn [10] formed several new phases from the reaction $\mathrm{Nb}_{2} \mathrm{O}_{5}(\mathrm{~s})+$ $3 \mathrm{NbX}_{5}(\mathrm{~g}) \rightleftarrows 5 \mathrm{NbOX}_{3}(\mathrm{~g}) \mathrm{X}=\mathrm{Cl}, \mathrm{Br}$, or I. One of the new phases formed in this reaction was called $\mathrm{B}$ and is the same phase which Laves named zeta. In this paper, the B-nomenclature is used. The stability field of $\mathrm{B}$ is shown in figure $4 . \mathrm{B}-\mathrm{Nb}_{2} \mathrm{O}_{5}$ is thus the medium temperature, high pressure polymorph of $\mathrm{Nb}_{2} \mathrm{O}_{5}$. B- $\mathrm{Nb}_{2} \mathrm{O}_{5}$ has not been previously synthesized by pressure equilibrium conditions below about $30 \mathrm{kbar}$ [2], but was found to form under equilibrium conditions in the present work at pressures as low as $3.5 \mathrm{kbar}$. 
This phase can be transformed reversibly, B- $\mathrm{Nb}_{2} \mathrm{O}_{5}$ $\leftrightarrows \mathrm{L}-\mathrm{Nb}_{2} \mathrm{O}_{5}$ and $\mathrm{B}-\mathrm{Nb}_{2} \mathrm{O}_{5} \rightleftarrows \mathrm{H}-\mathrm{Nb}_{2} \mathrm{O}_{5}$. However, B- $\mathrm{Nb}_{2} \mathrm{O}_{5}$ would not revert to $\mathrm{L}-\mathrm{Nb}_{2} \mathrm{O}_{5}$ at the low temperature boundary $\left(\mathrm{L}^{\prime}\right)$. This phase has been indexed after Laves, Petter, and Wulf [9] on the basis of a monoclinic unit cell. The parameters, $a=12.744$, $b=4.884, c=5.563 \AA$, and $\beta=105^{\circ} 1.9^{\prime}$, were refined by least squares analyses from the indexed $x$-ray powder pattern given in table 2 .

\section{3. $\mathrm{L}-\mathrm{Nb}_{2} \mathrm{O}_{5}$ (Low Temperature Form)}

\section{a. Stability}

The low temperature form of $\mathrm{Nb}_{2} \mathrm{O}_{5}\left(\mathrm{~L}-\mathrm{Nb}_{2} \mathrm{O}_{5}\right)$ was first reported by Brauer [11]. This is the apparently metastable form obtained when the material is precipitated from solution and crystallized at low temperatures. When heated this phase will gradually change to poorly formed $\mathrm{H}-\mathrm{Nb}_{2} \mathrm{O}_{5}$. which becomes more crystalline with increasing time and temperature. Once $\mathrm{H}-\mathrm{Nb}_{2} \mathrm{O}_{5}$ is formed it does not revert to $\mathrm{L}-\mathrm{Nb}_{2} \mathrm{O}_{5}$ at atmospheric pressure at any temperature.

The only oxide known to stabilize $\mathrm{L}-\mathrm{Nb}_{2} \mathrm{O}_{5}$ at a temperature in excess of $1000^{\circ} \mathrm{C}$ at ambient pressure is $\mathrm{Sb}_{2} \mathrm{O}_{4}[12]$. However, both $\mathrm{F}^{-}$and $(\mathrm{OH})^{-}$probably also can be incorporated into this structure type $[13,14]$ which may also result in stabilization. Apparently $\mathrm{L}-\mathrm{Nb}_{2} \mathrm{O}_{5}$ has a stability field at higher pressures and temperatures, as postulated by Wadsley and Andersson [1] and by Tamura [2]. In the present work, $\mathrm{H}-\mathrm{Nb}_{2} \mathrm{O}_{5}$ was transformed to $\mathrm{L}-\mathrm{Nb}_{2} \mathrm{O}_{5}$ and in turn $\mathrm{L}-\mathrm{Nb}_{2} \mathrm{O}_{5}$ was transformed to $\mathrm{H}-\mathrm{Nb}_{2} \mathrm{O}_{5}$ (see table 1). In figure 4, $\mathrm{L}-\mathrm{Nb}_{2} \mathrm{O}_{5}$ is shown to occur as both the low temperature-high pressure and high temperaturehigh pressure $\left(\mathrm{L}^{\prime}-\mathrm{Nb}_{2} \mathrm{O}_{5}\right)$ forms of $\mathrm{Nb}_{2} \mathrm{O}_{5}$ (see discussion sec. 5 ).

\section{b. Structure}

Numerous attempts to index the $\mathrm{x}$-ray powder diffraction pattern of $\mathrm{L}-\mathrm{Nb}_{2} \mathrm{O}_{5}$ have been reported in the literature. All such previous attempts were based on very limited powder data. Frevel and Rinn [15] first indexed $\mathrm{L}-\mathrm{Nb}_{2} \mathrm{O}_{5}$ with a monoclinic unit cell and the orthorhombic subcell was indicated by Holser [16] to be similar to that of $\mathrm{Ta}_{2} \mathrm{O}_{5}$ and $\mathrm{U}_{3} \mathrm{O}_{8}$. An orthorhombic unit cell for $\mathrm{L}-\mathrm{Nb}_{2} \mathrm{O}_{5}$ was proposed by Zvinchuck [17] with a $b$ axis approximately 12 times the subcell. Terao [18] also showed an orthorhombic subcell and postulated a monoclinic supercell for $\mathrm{L}-\mathrm{Nb}_{2} \mathrm{O}_{5}$ very similar to that of Frevel and Rinn [15]. From selected area electron diffraction of oxidized thin films, Spyridelis, Delavignette, and Amelinckx [19] reported that "in niobium pentoxide the spacing between the superlattice spots in the linear group is somewhat larger than in tantalum pentoxide corresponding to a smaller long spacing in direct space (which varies from 20 to $30 \AA$ )". The authors stated that although the specimen temperature is difficult to estimate on beam heating they felt that sufficient specimen heating had occurred so that they were observing diffraction data taken from a specimen of $\mathrm{H}-\mathrm{Nb}_{2} \mathrm{O}_{5}$. Subsequently, precharacterized specimens of $\mathrm{H}-\mathrm{Nb}_{2} \mathrm{O}_{5}$ were examined by Allpress, Sanders and Wadsley [20] by electron diffraction and found to be much different from the films described by Spyridelis et al. [19]. They concluded that, "in our opinion these films are much more likely to consist of low-temperature $\mathrm{T}-\mathrm{Nb}_{2} \mathrm{O}_{5} \quad\left(\mathrm{~L}-\mathrm{Nb}_{2} \mathrm{O}_{5}\right)$ or an oxygendeficient phase, or a mixture of phases closely related to it."

With increased temperature and pressure $\mathrm{L}-\mathrm{Nb}_{2} \mathrm{O}_{5}$ was found in the present work to become more crystalline and a number of superstructure lines become clearly evident in the $\mathrm{x}$-ray diffraction pattern. This pattern is very similar to that of the phase $15 \mathrm{Ta}_{2} \mathrm{O}_{5}$. $2 \mathrm{WO}_{3}$, the smallest unit cell found for the $\mathrm{L}-\mathrm{Ta}_{2} \mathrm{O}_{5}$ $\left(\mathrm{L}-\mathrm{Nb}_{2} \mathrm{O}_{5}\right)$ type phases $[21,22,23]$. The crystal structure of $15 \mathrm{Ta}_{2} \mathrm{O}_{5} \cdot 2 \mathrm{WO}_{3}$ has been reported by Stephenson and Roth [24] and the x-ray diffraction powder pattern was indexed on the basis of an orthorhombic unit cell with $a=6.175, b=29.29$, and $c=3.874 \AA$ with the aid of intensities obtained from single crystal diffractometer data. For this composition, the $b$-axis is eight times the subcell $(b=3.661 \times 8=29.29 \AA)$.

In the present work all of the lines of the powder pattern of $\mathrm{L}-\mathrm{Nb}_{2} \mathrm{O}_{5}$ can be indexed on the basis of an orthorhombic cell with $a=6.168 \pm .001, b=29.312$ \pm .001 and $c=3.936 \pm .001 \mathrm{~A}$, with $a$ and $c$ similar to the values previously reported for the subcell. As is the case with $15 \mathrm{Ta}_{2} \mathrm{O}_{5} \cdot 2 \mathrm{WO}_{3}$, the $b$ axis exhibits a multiplicity of 8 times the subcell and the true $b$ axis is $b=3.664 \times 8=29.312 \pm .001 \AA$. The indexed $\mathrm{x}$-ray diffraction powder pattern for $\mathrm{L}-\mathrm{Nb}_{2} \mathrm{O}_{5}$ is given in table $3 .^{3}$

Selected area electron diffraction patterns of L- $\mathrm{Nb}_{2} \mathrm{O}_{5}$ were made by J. G. Allpress, CSIRO, Melbourne, Australia, from a specimen heated to $1000{ }^{\circ} \mathrm{C}$ at $70,000 \mathrm{psi}$ for $19 \mathrm{~h}$. These patterns confirm that the correct unit cell is dimensionally orthorhombic with the parameters derived from the powder data. A typical example of diffraction from the $h k O$ plane is shown in figure 5 . It can be seen in this diffraction pattern that there is a multiplicity of 8 along the $b$ axis.

For a phase with $m=8$ the ideal composition is $\mathrm{M}_{16} \mathrm{O}_{42}[21,23,24]$. The compound $15 \mathrm{Ta}_{2} \mathrm{O}_{5} \cdot 2 \mathrm{WO}_{3}$ has the formula $\mathrm{Ta}_{15} \mathrm{WO}_{40.5}$ for eight subcells whereas the low temperature form of $\mathrm{Nb}_{2} \mathrm{O}_{5}$ would correspond to $\mathrm{Nb}_{16} \mathrm{O}_{40}$ with two oxygen ions missing and would have a slightly different ordering scheme. Since the crystal structure of $15 \mathrm{Ta}_{2} \mathrm{O}_{5} \cdot 2 \mathrm{WO}_{3}$ has been reported from single crystal data [24] it is possible to calculate the intensities of the x-ray diffraction powder pattern of this material. The Fortran program used for the computation was developed by Smith [25] and modified by Evans [26]. The calculated integrated intensities of the powder pattern agree quite well with those published for the observed powder data [22]. The integrated intensities for the $\mathrm{L}-\mathrm{Nb}_{2} \mathrm{O}_{5}$ powder pattern were calculated utilizing the same coordinates. The

${ }^{3}$ B. Nolander and R. Norin (Acta Chem. Scand. 263814 (1972)) have also indexed a powder pattern of "T- $\mathrm{Nb}_{2} \mathrm{O}_{5}$ " with the unit cell: $a=6.170, b=29.25, c=3.928 \AA$. 


\begin{tabular}{|c|c|c|c|c|c|}
\hline$n k \ell \underline{b}$ & dobs & ${ }^{2 \theta}$ obs & ${ }^{2 \theta} \mathrm{calc}$ & $\mathrm{I}_{\text {obs }} \underline{\mathrm{c} /}$ & $\mathrm{I}_{\mathrm{Cal}} \mathrm{c}^{\mathrm{d}}$ \\
\hline 130 & 5.217 & 16.98 & 16.98 & 5 & 6 \\
\hline 060 & 4.886 & 18.14 & 18.14 & 1 & 2 \\
\hline 001 & 3.934 & 22.58 & 22.57 & 88 & 100 \\
\hline 170 & -- & -- & 25.70 & -- & 3 \\
\hline 180 & 3.151 & 28.30 & 28.31 & 100 & 82 \\
\hline 200 & 3.085 & 28.92 & 28.93 & 44 & 33 \\
\hline 210 & 3.0680 & 29.08 & 29.09 & 15 & 22 \\
\hline 190 & -- & -- & 31.03 & -- & $<1$ \\
\hline 250 & 2.7298 & 32.78 & 32.78 & 5 & 1 \\
\hline 260 & 2.6078 & 34.36 & 34.36 & 3 & 1 \\
\hline 171 & 2.6080 & 34.46 & 34.46 & 1 & 2 \\
\hline 181 & 2.4597 & 36.50 & 36.50 & 48 & 36 \\
\hline 201 & 2.4278 & 37.00 & 37.00 & 21 & 14 \\
\hline 211 & 2.4200 & 37.12 & 37.13 & 10 & 9 \\
\hline $2,10,0$ & 2.1250 & 42.51 & 42.51 & 3 & 1 \\
\hline $1,13,0$ & 2.1177 & 42.66 & 42.66 & 4 & 2 \\
\hline 320 & -- & -- & 44.46 & -- & 1 \\
\hline $2,11,0$ & 2.1534 & 44.91 & 44.92 & 6 & 1 \\
\hline 330 & 2.0128 & 45.00 & 45.02 & 6 & 3 \\
\hline $1,14,0$ & 1.9828 & 45.72 & 45.72 & 1 & 2 \\
\hline 002 & 1.9689 & 46.06 & 46.08 & 24 & 19 \\
\hline $1,13,1$ & 1.8646 & 48.80 & 48.79 & 6 & 2 \\
\hline 370 & -- & --- & 49.34 & - & 2 \\
\hline $0,16,0$ & 1.8322 & 49.72 & 49.73 & 16 & 8 \\
\hline 321 & 1.8084 & 50.42 & 50.41 & 1 & 1 \\
\hline $\left.\begin{array}{l}380 \\
331\end{array}\right\}$ & 1.7931 & 50.88 & $\left\{\begin{array}{l}50.88 \\
50.90\end{array}\right\}$ & 23 & 12 \\
\hline 390 & -- & $\cdots$ & 52.60 & -- & 1 \\
\hline $\left.\begin{array}{l}371 \\
182\end{array}\right\}$ & 1.6693 & 54.96 & $\left\{\begin{array}{l}54.96 \\
54.96\end{array}\right\}$ & 24 & 20 \\
\hline $0,16,1$ & 1.6603 & 55.27 & 55.26 & 23 & 12 \\
\hline 202 & 1.6592 & 55.32 & 55.32 & 23 & 12 \\
\hline $2,15,0$ & 1.6507 & 55.63 & 55.63 & 3 & 2 \\
\hline 381 & 1.6316 & 56.34 & 56.34 & 15 & 9 \\
\hline 391 & -- & -- & 57.94 & -- & 1 \\
\hline $2,16,0$ & 1.5750 & 58.56 & 58.56 & 10 & 6 \\
\hline 400 & 1.5420 & 59.94 & 59.93 & 4 & 1 \\
\hline 410 & 1.5396 & 60.04 & 60.03 & 4 & 1 \\
\hline $3,13,0$ & 1.5195 & 60.92 & 60.93 & 3 & $<1$ \\
\hline 450 & 1.4912 & 62.20 & 62.19 & 1 & $<1$ \\
\hline 460 & -- & -- & 63.18 & -- & 1 \\
\hline $3,14,0$ & $-\overline{-1}$ & $\overline{-1}$ & 63.34 & $-\overline{0}$ & 1 \\
\hline $2,16,1$ & 1.4622 & 63.58 & 63.57 & 9 & 5 \\
\hline 401 & 1.4351 & 64.92 & 64.89 & 4 & 1 \\
\hline 332 & $1.40 / 0$ & 66.38 & 66.39 & 3 & 1 \\
\hline 372 & -- & - & 69.80 & $-\bar{c}$ & 1 \\
\hline $0,16,2$ & 1.3409 & 70.12 & 70.12 & 5 & 4 \\
\hline 382 & 1.3255 & 71.06 & 71.06 & 8 & 6 \\
\hline 003 & $\cdots$ & 71.90 & -- & -- & 2 \\
\hline
\end{tabular}

a/ Specimen heated to $700^{\circ} \mathrm{C}$ at 108,500 psi for 168 hours in a sealed $\mathrm{Pt}$ tube and quenched.

b/ Indexed on the basis of an orthorhombic unit cell $\underline{a}=6.199 \AA, \underline{b}=29.124 \AA$, and $\underline{c}=3.938 \AA$.

c/ observed intensity peak heights

d/ Calculated peak intensity using Fortran program described by D. Smith [25] and modified by E. Evans [26] (based on assumptions given in text).

following assumptions were made for the calculation: space group $\mathrm{Pm}$ was chosen, and the $z$ coordinates were fixed either at 0 or $1 / 2$. Oxygen number 21 (notation of [24]) was found to be absent 3 out of 4 times in two unit cells of $15 \mathrm{Ta}_{2} \mathrm{O}_{5} \cdot 2 \mathrm{WO}_{3}$ and assumed to be completely absent in $\mathrm{Nb}_{2} \mathrm{O}_{5}$. The calculated peak intensities of $\mathrm{L}_{-} \mathrm{Nb}_{2} \mathrm{O}_{5}$ [25] (given in table 3) were found to be in good agreement with those observed in the $\mathrm{x}$-ray powder diffraction pattern and to agree within experimental error with those calculated for $15 \mathrm{Ta}_{2} \mathrm{O}_{5}$. $2 \mathrm{WO}_{3}$. The $\mathrm{L}-\mathrm{Nb}_{2} \mathrm{O}_{5}$ specimen from which these computations were made was heated at $700{ }^{\circ} \mathrm{C}$ for

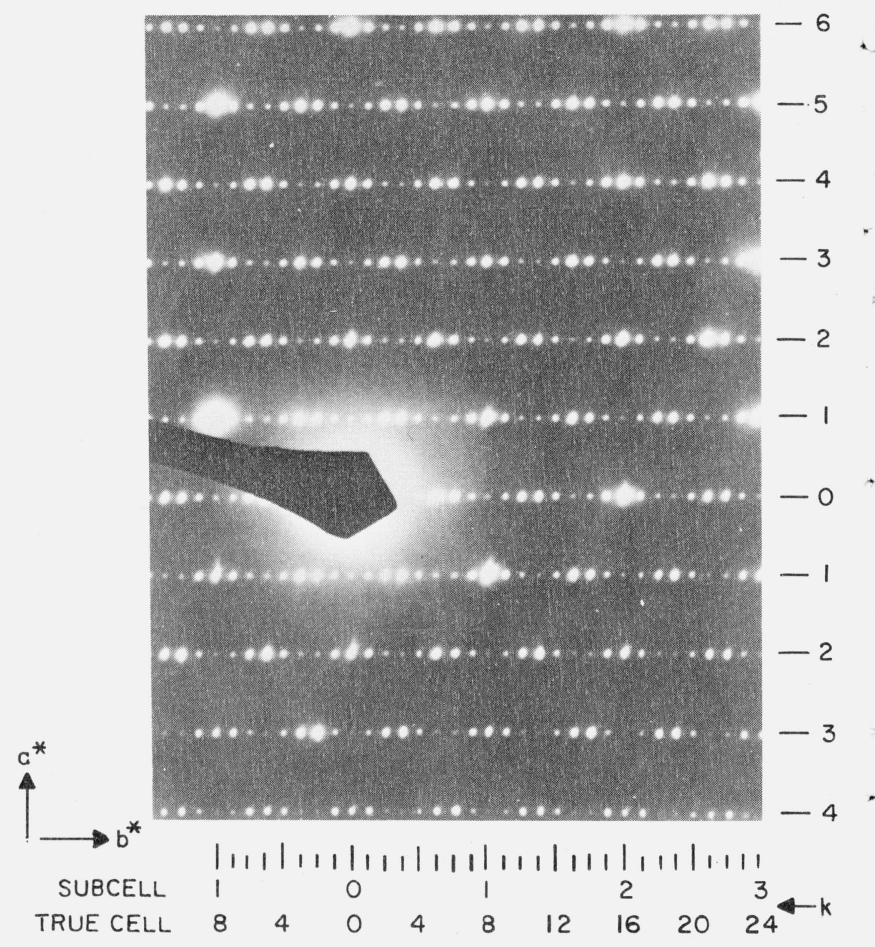

FIGURE 5. Selected area electron diffraction photograph of the hk0 plane of a crystal of $\mathrm{L}_{-} \mathrm{Nb}_{2} \mathrm{O}_{5}$ taken from a specimen heated to $1000^{\circ} \mathrm{C}$ at 70,000 psi for 19 hours.

The superstructure of 8 times the subcell is clearly evident, as marked on the lower margin.

$168 \mathrm{~h}$ at $108,500 \mathrm{psi}$. Since crystals in this specimen were too small for single crystal $\mathrm{x}$-ray diffraction studies, an attempt was made to grow single crystals of low $\mathrm{Nb}_{2} \mathrm{O}_{5}$ under pressure by the addition of $\mathrm{H}_{2} \mathrm{O}$. The resulting material was still very fine grained and unsuitable for single crystal x-ray diffraction studies. The x-ray powder pattern was indexed on the basis of a similar orthorhombic cell with the $b$ axis multiplicity of 8 and slightly different unit cell dimensions, $a=6.199$ $\AA, b=3.640 \times 8=29.124 \AA$, and $c=3.938 \AA$.

\section{Discussion}

In figure $4 . \mathrm{L}-\mathrm{Nb}_{2} \mathrm{O}_{5}$ and $\mathrm{L}^{\prime}-\mathrm{Nb}_{2} \mathrm{O}_{5}$ are shown to occur in two different portions of the system, separated by the field of $\mathrm{B}-\mathrm{Nb}_{2} \mathrm{O}_{5}$. The x-ray diffraction patterns of specimens prepared in these two fields are identical except for degree of crystallinity. There are at least two possible interpretations of the data.

The first possibility is that an unknown high temperature phase may be postulated to cool metastably through the B-field and then transform to a stable phase of the $\mathrm{L}-\mathrm{Nb}_{2} \mathrm{O}_{5}$ type. The low temperature form of $\mathrm{Nb}_{2} \mathrm{O}_{5}$ may possibly go through an infinite series of structurally subtle transitions of the sort reported for $\mathrm{L}-\mathrm{Ta}_{2} \mathrm{O}_{5}[21,24]$ involving a change in the multiplicity of the $b$ axis. This type of transition would involve a 
change in vacancy ordering and therefore in density. The structure of this original high temperature phase is, or course unknown, but may be postulated as being similar to $\mathrm{H}-\mathrm{Ta}_{2} \mathrm{O}_{5}$ (previously found for $\mathrm{Nb}_{2} \mathrm{O}_{5}$ only from melted specimens containing some $\mathrm{ZrO}_{2}$ [27]).

The second possibility is that a high temperaturehigh pressure polymorph may be assumed to be a phase of the $\mathrm{L}-\mathrm{Nb}_{2} \mathrm{O}_{5}$ type which, on cooling through the B-field metastably, goes through a series of transitions to the $m=8$ phase at atmospheric temperature and pressure. In the first case $\mathrm{L}-\mathrm{Nb}_{2} \mathrm{O}_{5}$ is the stable phase only in the low temperature-high pressure region. In the second case $\mathrm{L}-\mathrm{Nb}_{2} \mathrm{O}_{5}$ is stable only in the high temperature-high pressure region and the B-polymorph is stable to ambient temperature at high pressures. Either case is equally possible even if the $m=8$ phase is maintained at all temperatures and pressures. The correct situation could only be solved by a high resolution high pressure-high temperature (above $900{ }^{\circ} \mathrm{C}$ ) $\mathrm{x}$-ray study. Unfortunately such an apparatus was not available.

The authors wish to express their thanks to J. G. Allpress, CSIRO, Melbourne, Australia, for the electron diffraction examination, to $\mathrm{H}$. Yoder and $\mathrm{G}$. Speicher of the Geophysical Laboratory, Carnegie Institute of Washington for their many helpful comments during the course of this work, and to J. Filliben of the National Bureau of Standards for his help in the mathematical computation involved in the pressure measurement. The writers are especially indebted to instrument maker L. Schneider of NBS for his assistance in repairing and modifying the equipment.

\section{References}

[1] Wadsley, A. D., and Andersson, S., Perspectives in Structural Chemistry Vol. III, p. 1, edited by J. D. Dunitz and J. A. Ibers (John Wiley and Sons, New York, 1970).

[2] Tamura, S., J. Mater. Sci. 7298 (1972).

[3] Yoder, H. S., Jr., Trans. Amer. Geophy. Union 31827 (1950).

[4] Laus, F. A., Electrical Measurements, (McGraw-Hill, New York, 1938).
[5] Bell, P. M., Boyd, F. R., Jr., and England, J. L., Accurate Characterization of the High-Pressure Environment, Nat. Bur. Stand. (U.S.), Spec. Publ. 326, p. 63, edited by E. C. Lloyd (1971).

[6] Roth, R. S., Parker, H. S., Brower, W. S., and Waring, J. L., Fast Ion Transport in Solids, Solid State Batteries and Devices, sponsored by Advanced Study Institute, Belgirate, Italy (1972). Edited by W. vanGool (North Holland Publishing Co., Amsterdam, Holland, 1973), p. 217.

[7] Gatehouse, B. M., and Wadsley, A. D., Acta Cryst. 171545 (1964).

[8] Holzberg, F., Reisman, A., Berry, M., and Berkenbilt, M., J. Am. Chem. Soc. 813182 (1959).

[9] Laves, F., Petter, W., and Wulf, H., Naturwissenschaften 51 633 (1964).

[10] Schäfer, H., Schulte, F., and Gruehn, R., Angew. Chem. 76536 (1964).

[11] Brauer, G., Z. anorg. allgem Chem. 2481 (1941).

[12] Roth, R. S., and Waring, J. L., Amer. Min. 481348 (1963).

[13] Andersson, S., and Aström, Acta Chemica Scan. 182233 (1964).

[14] Jahnberg, L., and Andersson, S., Acta Chemica Scan. 21615 (1967).

[15] Frevel, L. K., and Rinn, H. N., Anal. Chem. 271329 (1955).

[16] Holser, W. T., Acta Cryst. 9196 (1956).

[17] Zvinchuck, R. A., Crystallography C.C.C.R. 3 744 (1958).

[18] Terao, N., Japanese Journal of Applied Physics 2156 (1963).

[19] Spyridelis, J. S., Delavignette, P., and Amelinckx, S., Phys. stat. sol. 19683 (1967).

[20] Allpress, J. G., Sanders, J. V., and Wadsley, A. D., Phys. stat. sol. 25 544 (1968).

[21] Roth, R. S., and Waring, J. L., J. Res. Nat. Bur. Stand. (U.S.), 74A (Phys. and Chem.), No. 4, 485-493 (July-Aug. 1970).

[22] Roth, R. S., Waring, J. L., and Parker, H. S., J. Solid State Chem. 2445 (1970).

[23] Roth, R. S., and Stephenson, N. C., The Chemistry of Extended Defects in Non-Metallic Solids, p. 167, Edited by L. Eyring and M. O'Keeffe, (North Holland Publishing Co., Amsterdam, 1970).

[24] Stephenson, N. C., and Roth, R. S., Acta Cryst. B27 1110 (1971).

[25] Smith, D. K., A. Revised Program for Calculating Powder Diffraction Patterns, Lawrence Radiation Laboratory, Livermore, Calif.

[26] Personal communication, E. Evans, National Bureau of Standards (1973).

[27] Roth, R. S., Waring, J. L., Brower, W. S., and Parker, H. S., NBS Special Publ. 364, p. 183, Proceedings of 5th Materials Research Symposium, Edited by R. S. Roth and S. J. Schneider (1972).

(Paper 77A6-793) 